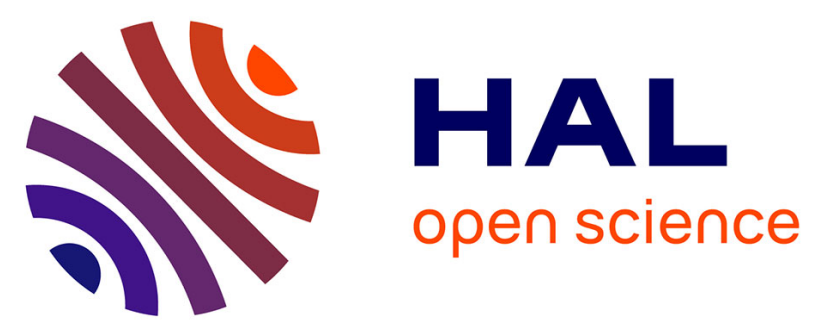

\title{
Modeling the dynamics of backyard chicken flows in traditional trade networks in Thailand: implications for surveillance and control of avian influenza
}

Anuwat Wiratsudakul, Mathilde Cécile Paul, Dominique J. Bicout, Thanawat Tiensin, Wannapong Triampo, Karine Chalvet-Monfray

\section{To cite this version:}

Anuwat Wiratsudakul, Mathilde Cécile Paul, Dominique J. Bicout, Thanawat Tiensin, Wannapong Triampo, et al.. Modeling the dynamics of backyard chicken flows in traditional trade networks in Thailand: implications for surveillance and control of avian influenza. Tropical Animal Health and Production, 2014, 46 (5), pp.845-853. 10.1007/s11250-014-0575-8 . hal-02016866

\section{HAL Id: hal-02016866 https://hal.science/hal-02016866}

Submitted on 14 Jun 2021

HAL is a multi-disciplinary open access archive for the deposit and dissemination of scientific research documents, whether they are published or not. The documents may come from teaching and research institutions in France or abroad, or from public or private research centers.
L'archive ouverte pluridisciplinaire HAL, est destinée au dépôt et à la diffusion de documents scientifiques de niveau recherche, publiés ou non, émanant des établissements d'enseignement et de recherche français ou étrangers, des laboratoires publics ou privés.

\section{(ㄷ)(i)}

Distributed under a Creative Commons Attribution| 4.0 International License 


\title{
Modeling the dynamics of backyard chicken flows in traditional trade networks in Thailand: implications for surveillance and control of avian influenza
}

\author{
Anuwat Wiratsudakul, Mathilde Cécile Paul, Dominique Joseph Bicout, Thanawat Tiensin, \\ Wannapong Triampo, Karine Chalvet-Monfray
}

\begin{abstract}
In Southeast Asia, traditional poultry marketing chains have been threatened by epidemics caused by the highly pathogenic avian influenza H5N1 (HPAI H5N1) virus. In Thailand, the trade of live backyard chickens is based on the activities of traders buying chickens from villages and supplying urban markets with chicken meat. This study aims to quantify the flows of chickens traded during a 1-year period in a province of Thailand. A compartmental stochastic dynamic model was constructed to illustrate trade flows of live chickens from villages to slaughterhouses. Live poultry movements present important temporal variations with increased activities during the 15 days preceding the Chinese New Year and, to a lesser extent, other festivals (Qingming Festival, Thai New Year, Hungry Ghost Festival, and International New Year). The
\end{abstract}

average distance of poultry movements ranges from 4 to $25 \mathrm{~km}$, defining a spatial scale for the risk of avian influenza that spread through traditional poultry marketing chains. Some characteristics of traditional poultry networks in Thailand, such as overlapping chicken supply zones, may facilitate disease diffusion over longer distances through combined expansion and relocation processes. This information may be of use in tailoring avian influenza and other emerging infectious poultry disease surveillance and control programs provided that the cost-effectiveness of such scenarios is also evaluated in further studies.

Keywords Avian influenza · Backyard chickens · Epidemiology $\cdot$ Live poultry traders $\cdot$ Stochastic model

\footnotetext{
A. Wiratsudakul

The Monitoring and Surveillance Center for Zoonotic Diseases in Wildlife and Exotic Animals, Faculty of Veterinary Science, Mahidol University, 999 Phuttamonthon 4 Rd., Salaya, Phuttamonthon, Nakhon Pathom 73170, Thailand
}

\section{J. Bicout}

Biomathematics and Epidemiology Unit, EPSP-TIMC, UMR 5525 CNRS, Joseph Fourier University and VetAgro Sup Campus Vétérinaire de Lyon, 1 Avenue Bourgelat, 69280 Marcy-l'Étoile, France

\section{T. Tiensin}

Division of Livestock Foreign Affairs, Department of Livestock Development, Ministry of Agriculture and Cooperatives, 69/1

Phayathai Rd., Ratchathewi, Bangkok 10400, Thailand

\section{W. Triampo}

Institute for Innovative Learning, and Biophysics Group, Department of Physics, Faculty of Science, Mahidol University, 999 Phuttamonthon 4 Rd., Salaya, Phuttamonthon, Nakhon Pathom 73170, Thailand 


\section{Introduction}

Thailand experienced four major epidemic outbreaks of highly pathogenic avian influenza H5N1 (HPAI H5N1) between 2004 and 2006. Sporadic cases were reported until late 2008 (Chantong and Kaneene, 2011). HPAI H5N1 is a lifethreatening zoonosis; 17 of the 25 recorded human cases in Thailand were fatal. It is also a disease of economic importance that directly affects poultry business in this country (Coker et al., 2011). It has been estimated that more than 65 million birds were destroyed to halt the outbreaks, and the government spent more than a billion Thai baht to compensate poultry owners. Most of the outbreaks reported in Thailand concerned backyard poultry (Chantong and Kaneene, 2011). Backyard poultry production was also implicated in the transmission of HPAI H5N1 in the beginning of several epidemics in other countries (Alders et al., 2013). A better understanding of the disease dynamics of the backyard poultry sector will aid in controlling the spread and persistence of HPAI H5N1.

Backyard chicken is the predominant population present in the poultry sector in Thailand. Backyard chickens, as a part of agricultural lifestyle, are raised in villages for many purposes including religious or traditional ceremonies, cock fighting, home consumption, and cash income. Usually, households raise from 30 to 50 chickens of marketable size annually (Choprakarn and Wongpichet, 2007) and sell them occasionally to live poultry traders supplying urban markets with chicken meat (Paul et al., 2013). In most low-income, fooddeficit countries, village poultry production contributes to the majority of poultry production. In the twenty-first century, it still makes critically important contributions to poverty alleviation, household food security, and women's empowerment in many tropical countries (Alders et al., 2013).

A series of studies carried out in Cambodia (Van Kerkhove et al., 2009; Fournie et al., 2012), Vietnam (Fournie et al., 2012, 2013), and China (Martin et al., 2011; Soares Magalhaes et al., 2012) indicate that poultry trade networks play a major role in the spread and persistence of HPAI H5N1, and that live bird markets constitute a critical "hub" (Van Kerkhove et al., 2009). Findings also suggest that poultry trade seasonality may affect the risk of HPAI H5N1 spread (Soares Magalhaes et al., 2012). Most studies focused on the influence of the Chinese New Year only, and quantitative data on the spatial and temporal dynamics of poultry flows in Southeast Asia are still lacking. Moreover, although the pattern of live poultry trade in Thailand may differ from that of other Asian countries, it is still poorly explored. Unlike Cambodia, Vietnam, and China, live bird markets are rare in Thailand (Tiensin et al., 2009). Backyard poultry trade in this country is based on a network of traders who purchase live chickens in villages and gather them at home for slaughter or sale to slaughterers. Chicken traders may play a key role in HPAI H5N1 dispersal in Thailand (Paul et al., 2013), but most studies in this country focused only on farmers and markets (Poolkhet et al., 2012, 2013).

The present study aimed at quantifying live chicken flows in traditional trade chains in Thailand, analyzing their spatial and temporal variations during a 1 -year period, and examining the implications of these movements for the design of surveillance and control programs for avian influenza, including HPAI H5N1 or other recent emerging subtypes.

\section{Material and methods}

\section{Study site}

Phitsanulok, the province that recorded the highest number of confirmed HPAI H5N1 outbreaks in chickens during the first and second epidemic waves in Thailand (Paul et al., 2011), was chosen for this study. The backyard chicken population in Phitsanulok province was estimated at 1,546,959 birds, according to an active avian influenza surveillance program carried out in March 2012 by the Department of Livestock Development. Backyard chickens represented $82.47 \%$ of all poultry and $93.63 \%$ of flocks in the province at that time.

\section{Data collection}

A field survey was conducted from June to August 2012 to collect detailed information on backyard poultry trade in the province. The first step was to investigate the practices of 20 chicken traders in Phitsanulok using a questionnaire. These traders were selected from a database constituted in a previous study (Paul et al., 2013). The database was updated for this study by a snowball sampling method (Sadler et al., 2010). Traders were questioned about their poultry trade activities during normal period and festivals. The questionnaire included specific questions regarding the location of the traders and of the flocks from which they collected their chickens, their relationships with farmers and other traders, and the number of chickens involved in transactions. The questionnaire distinguished various periods of the year, normal period, Chinese New Year, and other festivals (traders were free to mention information for as many festivals as they wished). In the second step, the activity of four traders was scrutinized. Each trader was followed daily for 2 weeks by the first author during the morning and evening chicken collection runs. Traders' movements were tracked using a GPS tracking device. Information was collected on the number of chickens bought, sold, or slaughtered by each trader, as well as the age and sex of chickens. Questions were also asked to evaluate whether the quantity of chickens collected and distance traveled varied over the year. Similar information (number of chickens available, with age and sex, depending on period of 
the year) was collected on the poultry population present in all the households that were visited.

Principles of the dynamic model

A compartmental stochastic dynamic model was constructed to analyze the dynamic flow of backyard chicken within villages and from villages to slaughterhouses via different types of traders. The conceptual model is shown in Fig. 1. The unit of interest was the village (the smallest administrative unit of Thailand called Moo-baan in Thai). We considered backyard chickens in a village as a whole homogeneous population, as chickens are raised without any fences and are thus likely to mix with chickens from other households during daytime (Choprakarn and Wongpichet, 2007). The model was divided into two parts: village and trader. The village part comprised three compartments: young chickens (aged $<5$ months old), ready-to-sell chickens, and stocked chickens. Traders were subdivided into three types: traderslaughterhouse (TS), collecting chickens from villages, and slaughtering them by themselves; household trader (HT), collecting chickens from villages, and selling them to other traders; and trader of trader (TT), buying chickens collected by HTs, and slaughtering them. The model was initialized with a distribution of backyard chickens into the three village compartments using the parameters described in Table 1.
The village part of the model was run simultaneously in all 1,045 villages located in the Phitsanulok Province. The flow of chickens started with animals from the young chicken compartment leaving the compartment as they grew older. Half of all grown chickens stochastically moved into the stocked compartment and the remaining half to the ready-tosell compartment. In each village, dead chickens were consecutively removed from each compartment as time passed by, and the young chicken compartment was refilled by hatchlings produced from stocked chickens or imported from elsewhere with the probability shown in Table 1. Backyard chickens in the ready-to-sell compartment can transit into either the HT or TS compartments. All chickens collected in the HT compartments were then aggregated into the TT compartments. Finally, all chickens from the TS and TT compartments were slaughtered. The model was stochastically run for 1,000 simulations. All mathematical equations used for constructing the model are available in Online Resource 1.

\section{Social network analysis}

Social networks of traditional live backyard chicken trade were simulated 1,000 times. In these networks, a node was referred to a village and a tie was referred to trading activities that occurred between a village and a trader. Given that each trader was a part of the village, the trader was also counted as a

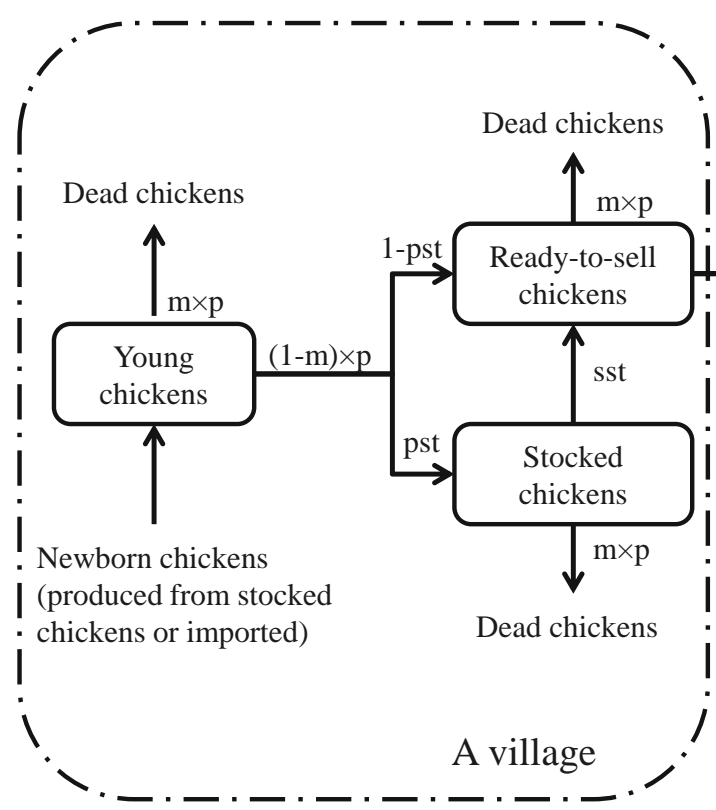

Fig. 1 A conceptual model representing the organization of traditional live backyard chicken trade in one village located in Phitsanulok Province, Thailand. The model functions in the same manner in all villages of the province included in the 1,000 simulations. The parameters used in this model are as follows: $m$ daily probability of mortality, $p$ daily probability of young chickens to leave the young chicken compartment, pst proportion of young chickens that flow into the stocked chicken compartment, sst daily probability of retired stocked chickens to leave

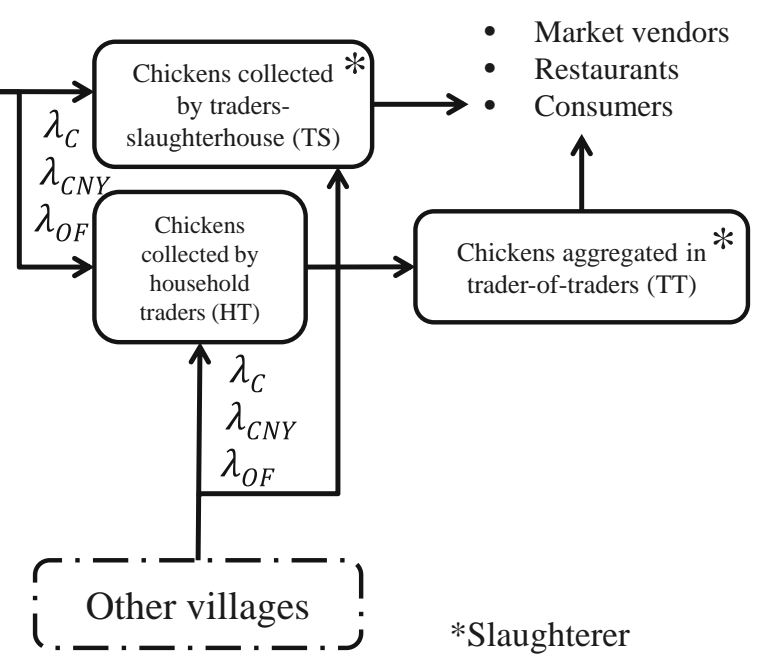

the stocked chicken compartment, $\lambda_{\mathrm{C}}$ lambda of number of chickens collected per village per day during normal periods, $\lambda_{\mathrm{CNY}}$ lambda of number of chickens collected per village per day during the Chinese New Year, and $\lambda_{\mathrm{OF}}$ lambda of number of chickens collected per village per day during other festivals, namely the Qingming Festival, the Thai New Year, the Hungry Ghost Festival, and the International New Year. Lambda corresponds to the mean of Poisson distribution. The compartments with asterisk are the compartments in which the chickens are slaughtered 
Table 1 Parameters used in developing the compartmental stochastic dynamic model of live backyard chicken flows within villages and along trade chain in Phitsanulok province, Thailand

\begin{tabular}{|c|c|c|}
\hline Parameters & Value & Origin \\
\hline \multicolumn{3}{|l|}{ Village part } \\
\hline Proportion of young chickens in total population ( $p y)$ & 0.55 & Field observation \\
\hline Daily probability of young chickens to leave the young chicken compartment $(p)$ & $1 /(5 \times 30)$ & Literature $^{\mathrm{b}}$ \\
\hline Proportion of young chickens that flow into the stocked chicken compartment ( $p s t$ ) & 0.5 & Field observation \\
\hline Daily probability of retired stocked chickens to leave the stocked chicken compartment (sst) & $0.1 /(5 \times 30)$ & Trader interviews \\
\hline Daily probability of mortality $(m)$ & $0.5 /(5 \times 30)$ & Literature $^{\mathrm{b}}$ \\
\hline \multicolumn{3}{|l|}{ Trader part } \\
\hline Lambda of number of villages visited by a trader during normal period $\left(\lambda_{\mathrm{NBV}}\right)^{\mathrm{a}}$ & 0.85 & Trader interviews \\
\hline Number of villages visited during festival periods & $1-3$ & Trader interviews \\
\hline Lambda of number of chickens collected per village per day during normal period $\left(\lambda_{C}\right)$ & 16 & Trader interviews \\
\hline Lambda of number of chickens collected per village per day during Chinese New Year $\left(\lambda_{\mathrm{CNY}}\right)$ & 55.3 & Trader interviews \\
\hline Lambda of number of chickens collected per village per day during other festivals $\left(\lambda_{\mathrm{OF}}\right)$ & $55.3 / 2$ & Trader interviews \\
\hline Minimum number of chickens in the villages that traders prefer to visit & 100 & Field observation \\
\hline Number of non-repeated day & 15 & Field observation \\
\hline
\end{tabular}

${ }^{a}$ Lambda corresponds to the mean of Poisson distribution

${ }^{\mathrm{b}}$ Choprakarn and Wongpichet, 2007

node. The social network parameter used in this study was degree centrality. Degree centrality is defined as the number of immediate ties that each node has (Frantz, 2012). Here, degree centrality was defined as the number of connections between villages and traders. In this model, villages could not connect with one another without traders.

All statistical and geographical analyses were performed using statistical computing language $\mathrm{R}$ version 3.0.1 ( $\mathrm{R}$ development Core Team, Vienna, Austria).

\section{Results}

Characteristics of poultry movements and input parameters for network connectivity

Of the 20 traders surveyed, nine were HTs, eight were TSs, and three were TTs. One of the TSs we met moved both chickens and ducks, while the others moved chickens only. In the model, we considered only chickens as duck movements were very limited. Compared with normal period, traders collected more chickens during the 15-day period preceding five festivals: Chinese New Year (days 17-31 of the year), Qingming Festival and Thai New Year (days 81105), Hungry Ghost Festival (days 228-242), and International New Year (days 351-365). Traders collected twice as many animals during the Chinese New Year as during the other four festivals. Consequently, the Qingming Festival and the Thai New Year, the Hungry Ghost Festival, and the International New Year were modeled under the same parameters and assumptions. The days stated here are defined according to the Gregorian calendar.

The field study showed that traders located in remote areas worked only within their own village and had sporadic activities. Hence, the study area was finally restricted to 672 villages of the Muang District (Phitsanulok City) and its contiguous suburban districts (of 1,045 villages in the province). In all, the first author followed traders to 42 households located in 38 villages. TSs and HTs traveled $6.06 \mathrm{~km}$ at most to collect backyard chickens. In the model, the maximum distance traveled by TSs and HTs was therefore set at a 7 $\mathrm{km}$ radius around villages. Because we found eight TSs and three TTs in our field survey, the same number of TSs and TTs was applied in the model to mimic field observations. However, the number of HTs was different for each TT. The number of observed HTs could not be directly applied. Consequently, the randomly simulated number of HTs for each TT was used instead. In the current model, we assigned 6,8 , and 12 HTs for the three TTs involved respectively. The locations of all traders were randomly simulated and restricted only within Muang District in order to mimic what was observed. Traders are usually installed near the large markets located in urban areas.

Simulation: model outputs

Results from social network analysis showed that the mean degree centrality between villages and traders was $2.0(95 \%$ confidence interval $[\mathrm{CI}]=1.7-2.6$ ), with a maximum of 2.7. A sociogram of the network, randomly selected from the 1,000 simulations, is displayed in Fig. 2. 


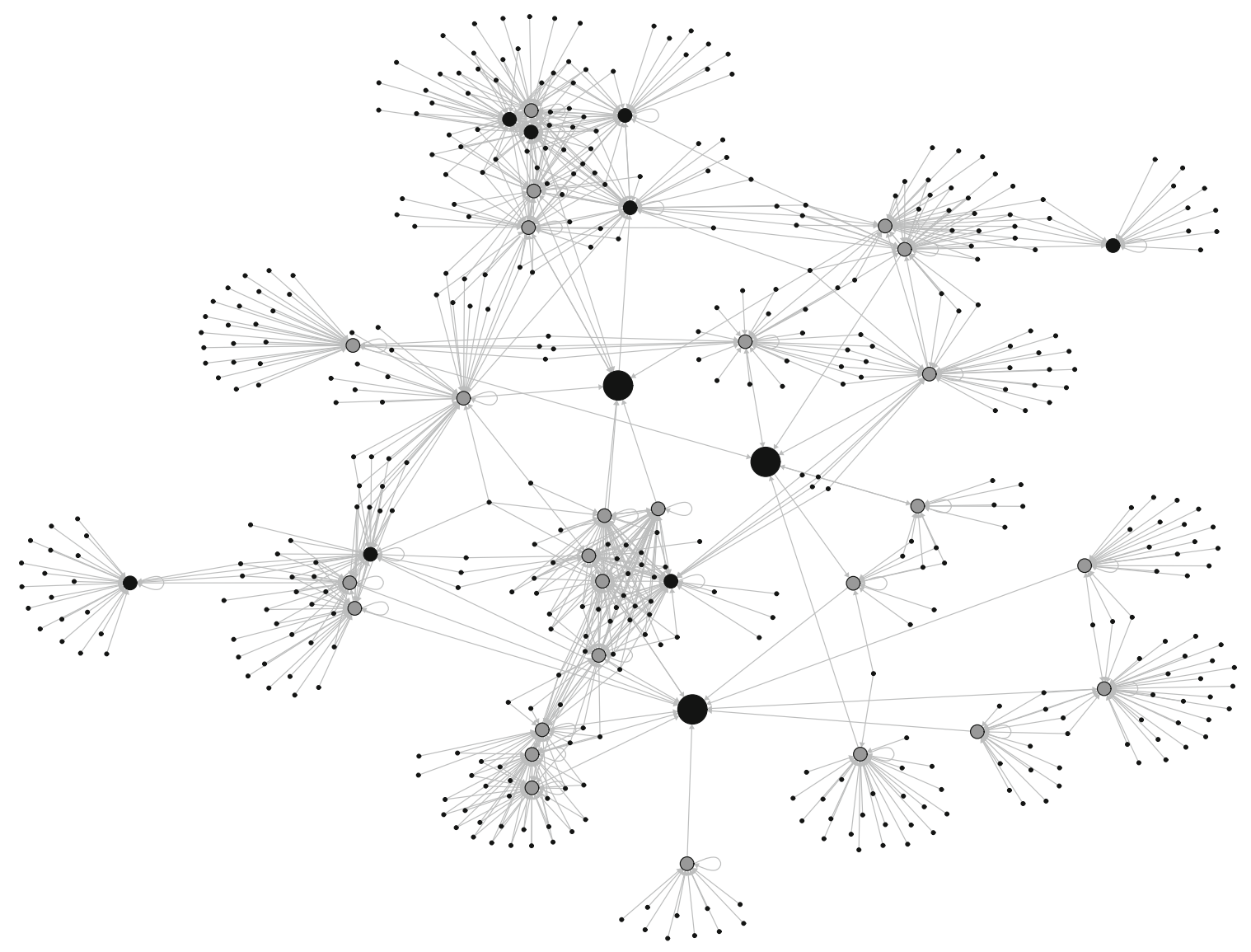

Fig. 2 A static sociogram of one simulated live backyard chicken trade network in Phitsanulok Province, Thailand, in a 1-year period. This sociogram contains 467 nodes and 953 ties. Each node represents a village. Black small-sized nodes show villages without traders. Black medium-sized nodes indicate villages with trader-slaughterhouses (TSs). Gray medium-sized nodes show the villages with household traders (HTs), and the big black nodes illustrate the villages with traders of traders (TTs)

Figure 4 shows that each village was visited by an average of 1.5 traders during the Chinese New Year festival $(95 \% \mathrm{CI}=$ $1.2-1.7)$ and 1.3 traders during other periods $(95 \% \mathrm{CI}=1.1-$ 1.5). Because TTs always visit their regular suppliers (HTs located in certain villages), the number of villages they visited was constant throughout the year.

The bivariate plots of distances traveled to collect chickens and the number of chickens collected are shown in Fig. 5. These plots show that TSs and HTs collected approximately 41.5 chickens each time during the Chinese New Year festival (95 \% CI=18.8-54.4) and only 20.0 (95\% CI=15.4-25.6) and 15.3 chickens (95\% CI=15.0-15.6) during the Hungry Ghost Festival and normal periods, respectively. The average distance traveled to collect chickens was $4.4 \mathrm{~km}(95 \% \mathrm{CI}=$ 4.2-4.5) in all periods. The mean number of chickens collected by TTs each time was 62.7 chickens during the Chinese New Year (95\% CI=22.6-95.3), 26.2 chickens during the Hungry Ghost Festival (95 \% CI=19.7-36.8), and 19.4 chickens during normal periods (95\% CI=18.5-20.2). Distance traveled to HTs' locations ranged from 24.9 to $25.2 \mathrm{~km}$ (95\% CI=24.2-25.9). 
Fig. 3 a Histogram of total number of visits made by slaughterhouse traders (TSs) and household traders (HTs) to all villages and $\mathbf{b}$ histogram of number of distinct villages visited per traders in a year-round period (days 1-365). The plots were illustrated from average values of 1,000 simulations

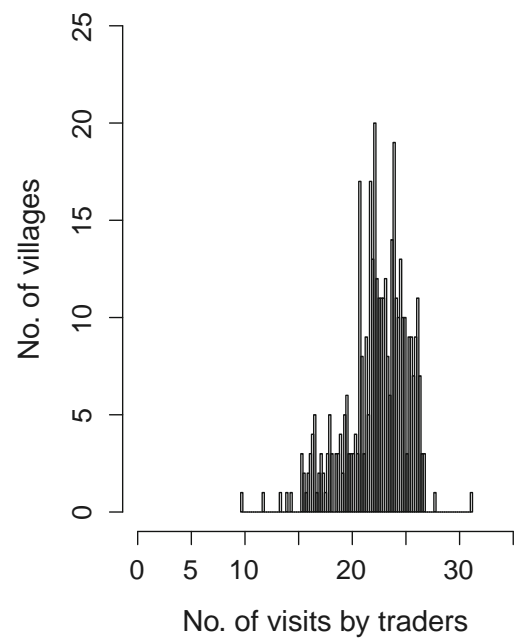

b

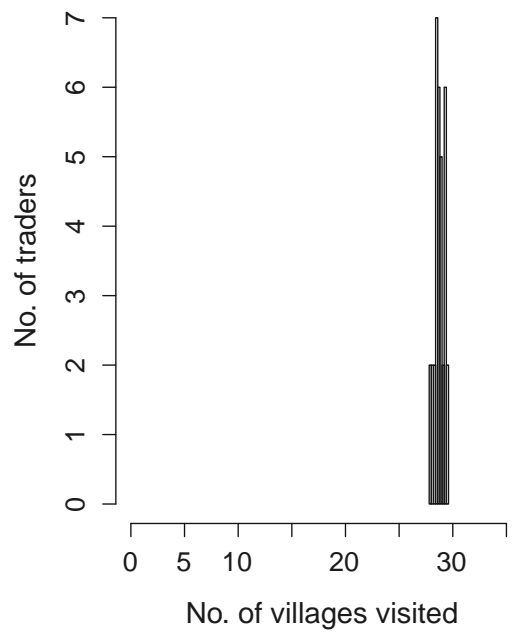

\section{Discussion}

In the present study, mathematical modeling of poultry flows along traditional live poultry trade networks from villages to slaughterhouse made it possible to examine quantitative indicators for poultry movements.

Before further conclusions are drawn, one should note that the present study was conducted during a period during which no epidemics occurred. Disease outbreaks may alter the movements of chickens. Thus, the results of this study may be mainly applicable to the period when the infection is present but not yet diagnosed or when epidemics are of limited extent. Further studies are necessary to evaluate the impact of disease epidemics on the pattern of live chickens' movements. Also, fighting cocks, which can be reared together with other backyard chickens, were not considered in our study. Siengsanan-Lamont et al. (2013) indicated that some fighting cock owners moved their fighting cocks across provinces, but the actual distances traveled by fighting cocks' owners have not been studied yet in Thailand. In the present study, we focused on the trade networks supplying backyard chickens meat to markets; fighting cocks participate only sporadically to these networks, as their old age diminishes the value to which they can be sold for meat. Despite these limitations, findings from this study may help to identify critical points regarding the surveillance and control of avian influenza viruses, including HPAI H5N1.

First, this study produced a quantitative global picture of poultry movements during a 1-year period. The total amount of chickens traded in traditional networks in Thailand is small

Table 2 Summary of outcomes generated from 1,000 simulations of the stochastic dynamic model for live poultry flows in traditional backyard chicken trade chains in Thailand during normal periods, Chinese New Year festival, and Hungry Ghost Festival

\begin{tabular}{|c|c|c|c|c|c|c|}
\hline \multirow[t]{3}{*}{ Parameter } & \multicolumn{6}{|l|}{ Period } \\
\hline & \multicolumn{2}{|l|}{$\begin{array}{l}\text { Normal period } \\
\text { (days } 336-350) \\
\text { Mean }(95 \% \mathrm{CI})\end{array}$} & \multicolumn{2}{|l|}{$\begin{array}{l}\text { Chinese New Year } \\
\text { (days } 17-31) \\
\text { Mean }(95 \% \mathrm{CI})\end{array}$} & \multicolumn{2}{|l|}{$\begin{array}{l}\text { Hungry Ghost Festival } \\
\text { (days 228-242) } \\
\text { Mean }(95 \% \text { CI) }\end{array}$} \\
\hline & TS and HT & $\mathrm{TT}$ & TS and HT & $\mathrm{TT}$ & TS and HT & $\mathrm{TT}$ \\
\hline $\begin{array}{l}\text { Total number of villages } \\
\text { visited by all traders }\end{array}$ & 309 (279-339) & 26 & $369(343-423)$ & 26 & $345(304-378)$ & 26 \\
\hline $\begin{array}{l}\text { Average number of villages } \\
\text { visited by each trader }\end{array}$ & $12.9(12.7,13.1)$ & $8.7(6-12)$ & $18.7(12.5-25.1)$ & $8.7(6-12)$ & $15.1(12.7-20.9)$ & $8.7(6-12)$ \\
\hline $\begin{array}{l}\text { Total number of chickens } \\
\text { caught by all traders }\end{array}$ & $6,737(6,007-8,478)$ & $5,152(4,569-5,761)$ & $26,082(24,046-28,099)$ & $18,782(17,084-20,360)$ & $10,133(8,779-11,297)$ & $7,503(6,446-8,478)$ \\
\hline $\begin{array}{l}\text { Average number of chickens } \\
\text { caught by each trader per } \\
\text { each catching }\end{array}$ & $15.3(15.0-15.6)$ & $19.4(18.5-20.2)$ & $41.5(18.8-54.4)$ & $62.7(22.6-95.3)$ & $20.0(15.4-25.6)$ & $26.2(19.7-36.8)$ \\
\hline $\begin{array}{l}\text { Average distance each trader } \\
\text { travels to catch chickens } \\
\text { per each catching }(\mathrm{km})\end{array}$ & $4.4(4.2-4.5)$ & $25.2(24.2-25.9)$ & $4.4(4.2-4.5)$ & $24.9(24.2-25.9)$ & $4.4(4.2-4.5)$ & $25.0(24.2-25.7)$ \\
\hline
\end{tabular}

TS trader-slaughterhouse, HT household trader, TT trader of trader 
Fig. 4 Histogram of number of distinct traders visiting villages during the Chinese New Year (days 17-31), the Hungry Ghost Festival (days 228-242), and normal periods (days 336-350) The plots were illustrated from average values of 1,000 simulations
Normal period

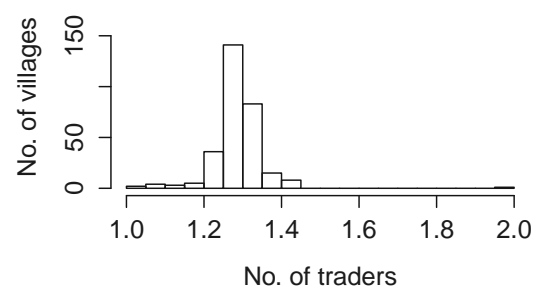

Hungry Ghost Festival

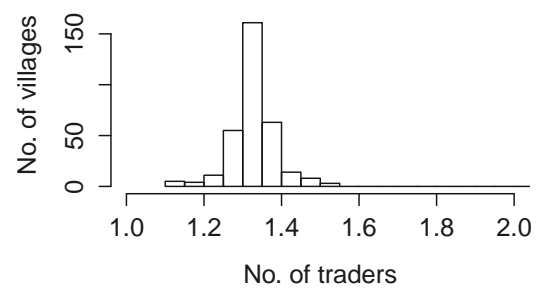

Chinese New Year

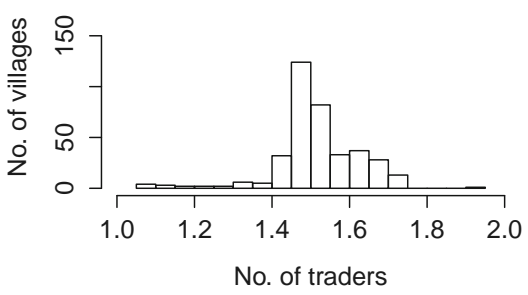

when compared with other production systems present in Thailand (Chantong and Kaneene, 2011) or in other countries (Van Kerkhove et al., 2009; Soares Magalhães et al., 2010; Soares Magalhaes et al., 2012). Thus, the risk for HPAI H5N1 that spreads through traditional poultry market chains may appear limited. However, traditional trading patterns still pose some important surveillance and control challenges. Indeed, these chickens flow through networks that are invisible to veterinary authorities because they are organized informally (Paul et al., 2013). Thus, they are almost impossible to
Fig. 5 Bivariate plots of distances traveled by traders to collect chickens ( $x$-axis) and number of chickens collected $(y$ axis) during the Chinese New Year (days 17-31), the Hungry Ghost Festival (days 228-242), and normal periods (days 336 350). Three plots on the left represent situations of traderslaughterhouses (TSs) and household traders (HTs), and three plots in the right-hand side depict situations of traders (TTs). The plots were illustrated from average values of 1,000 simulations
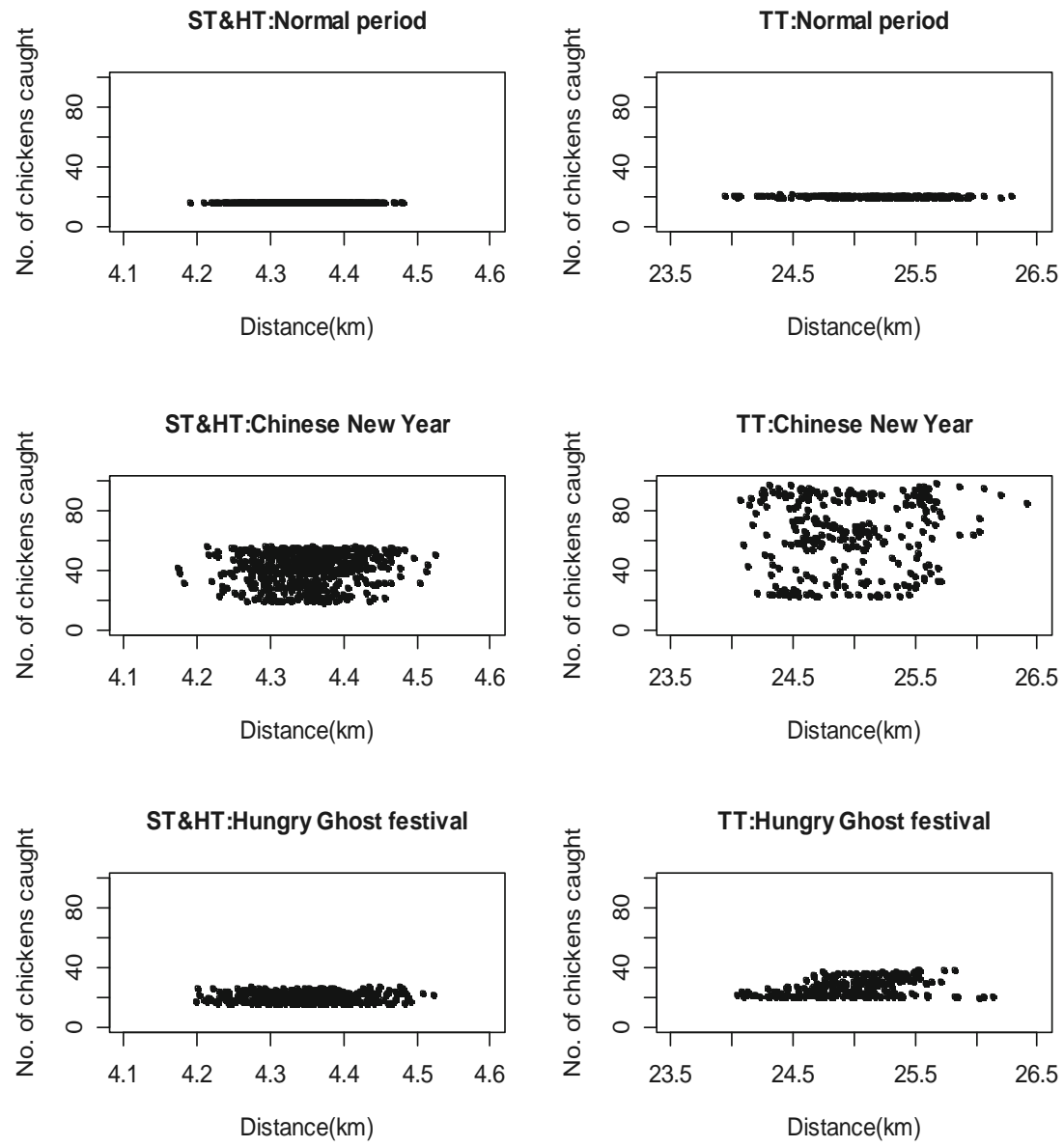
monitor and to regulate. Even if the amount of chickens is small, poultries are being traded all year round and may thus contribute to spread HPAI H5N1 silently. In 1 year, traders visited approximately $75 \%$ of all villages in the modeled area. The mechanism by which traders may participate to the spread of avian influenza viruses has been described in previous studies (Fournie et al., 2012; Paul et al., 2013). Briefly, the $\mathrm{H} 5 \mathrm{~N} 1$ virus can easily be transported from one farm to another along a trader's daily route through direct contact between transported poultry and poultry on visited households (potentially infected excretions or mucus may fall from cages to the ground). The virus can also be spread by indirect transmission through bamboo cages (which are easily soiled and difficult to clean), vehicles, or other materials. The social network analysis showed that each village was visited by an average of two different traders in 1 year. Thus, in Thailand, disease spread may be facilitated by overlapping trade zones.

Second, this study quantified flows of backyard chicken trade. The study made it possible to distinguish the role of TSs and HTs from those of TTs in poultry movements and to discuss their potential role for the spread of avian influenza viruses. In the present study, we found that TSs and HTs collect chickens within a $4.4-\mathrm{km}$ radius. The extent of TSs and HTs' collection zone is constrained by the fact that they have limited financial resources and travel using motorcycles. Our finding is thus consistent with studies carried out in Thailand (Poolkhet et al., 2012), indicating that traders conducted business only near their villages and in Vietnam (Soares Magalhães et al., 2010) where it was found that traders using motorcycles transported chickens on a short distance. Here, TSs and HTs visited a considerable number of villages in a short time span, transporting animals from one village to another. In Thailand, TSs and HTs may therefore contribute to the rapid spread of avian influenza locally. In contrast with previous studies (Poolkhet et al., 2012, 2013), we found that in Thailand, TTs range over a larger area and handle approximately $75 \%$ of all backyard chickens collected, although they visit significantly fewer villages. Their activity may play an important role in the spread of avian influenza, as they provide sporadic medium distance jumps between villages. In summary, the present study highlights how the structure of backyard poultry trade networks in Thailand may contribute to disease diffusion through combined expansion and relocation processes, which are facilitated by overlapping trade zones. Once introduced in a village by a trader, avian influenza virus may spread in the village's poultry population and jump later to a distant group of villages through the visit of another trader, especially if it is a TT. The $5-\mathrm{km}$ radius of poultry movement control, which was implemented by Thai authorities at the beginning of HPAI H5N1 outbreaks (Tiensin et al., 2005), may have contributed to successfully controlling disease spread by limiting local movements.
Third, this paper also highlighted the temporal variations of live poultry movements during a 1 -year period. We found that during the Chinese New Year, the total number of chickens moved by TSs and HTs in 15 days increased by $387 \%$ and those moved by TTs increased by $364 \%$. This is consistent with studies carried out in other countries (Van Kerkhove et al., 2009; Soares Magalhaes et al., 2012). The number of villages visited by all types of traders also increased significantly during the Chinese New Year. However, contrary to the findings from China (Soares Magalhaes et al., 2012), we did not find in Thailand any variation of traders' trade zones during the Chinese New Year. One could argue that this may result from model parameterization, which sets the maximum radius of traders' catchment area constant over the year. However, catchment radius was allowed in the model to vary below this maximum. Thus, according to our dynamic model of poultry population, even if traders need to collect more chickens during the Chinese New Year, a sufficient supply was available within an average radius of 4 to $25 \mathrm{~km}$ around their house. The type of vehicle appears to determine the distance that traders can travel and the number of chickens collected: TSs and HTs generally used motorcycles equipped with baskets or motor tricycles to transport animals, whereas the TTs used pickup trucks. Figure 5 shows that TSs and HTs travel shorter distances and transport less chickens per trip compared with TTs in all studied periods.

In Thailand, HPAI H5N1 may spread faster during the 15 days preceding the Chinese New Year festival because of the important increase of live backyard chicken trade when compared with normal period of the year. However, in comparison with China and Cambodia, where distances and trade volume increased widely during the Chinese New Year festivities (Van Kerkhove et al., 2009; Soares Magalhaes et al., 2012), the risk for long distance spread of avian influenza viruses through informal poultry trade networks is probably much less in Thailand. The Chinese New Year has already been identified by Thai authorities as a key period regarding the risk of avian influenza and has been taken into account by risk-based surveillance systems. Indeed, the active surveillance program called $X$-ray campaigns, in which 750,000 village health volunteers look for clinical cases of HPAI H5N1 and collect biological samples, have been conducted since 2004 during the month preceding the Chinese New Year festivities (Tiensin et al., 2005). We also found that poultry movements and number of villages visited by traders increased during other festivals. Risk-based surveillance programs could also target these periods, but given the moderate increase of poultry movements during these festivals, further studies are needed to evaluate the cost-benefit of such scenario.

Traditional trading patterns still pose some important challenges regarding surveillance and control. This study quantified flows of live backyard chickens in one province of 
Thailand during a 1-year period. This study also highlighted the temporal variations of live poultry movements, which were intensified during the 15 days preceding the Chinese New Year and, to a lesser extent, during four other festivals. This information could be used for tailoring risk-based surveillance and control programs for avian influenza or other avian infectious diseases provided that the cost-effectiveness of such scenarios is also evaluated in further studies.

Acknowledgments The authors are grateful to the Franco-Thai PHC Program in Higher Education and Research for their financial support in the field survey. We gratefully thank Ms. Thitiya Seekhsamban, Ms. Poonyapat Sedwisai, and Ms. Tatiyanuch Chamsai for their contributions in the field study. We acknowledge the Department of Livestock Development, Ministry of Agriculture and Cooperatives of Thailand for providing the backyard chicken census data, and we thank all live backyard chicken traders for their participation in this work. We are grateful to Dr. Ann Dernburg for the manuscript reviews. We thank the three reviewers for their valuable comments and suggestions.

Conflict of interest The authors declare that there is no conflict of interest.

\section{References}

Alders, R., Awuni, J.A., Bagnol, B., Farrell, P. and de Haan, N., 2013. Impact of avian influenza on village poultry production globally, Ecohealth, 1-10.

Chantong, W. and Kaneene, J.B., 2011. Poultry raising systems and highly pathogenic avian influenza outbreaks in Thailand: the situation, associations, and impacts, The Southeast Asian Journal of Tropical Medicine and Public Health, 42, 596-608

Choprakarn, K. and Wongpichet, K., 2007. Village chicken production systems in Thailand. In: O. Thieme and D Pilling (eds.), Proceedings of the international poultry conference, Bangkok, Thailand, November 5-7, 2007, 63-64

Coker, R.J., Hunter, B.M., Rudge, J.W., Liverani, M. and Hanvoravongchai, P., 2011. Emerging infectious diseases in southeast Asia: regional challenges to control, Lancet, 377, 599-609

Fournie, G., Guitian, J., Desvaux, S., Mangtani, P., Ly, S., Cong, V.C., San, S., Dung do, H., Holl, D., Pfeiffer, D.U., Vong, S. and Ghani, A.C., 2012. Identifying live bird markets with the potential to act as reservoirs of avian influenza A (H5N1) virus: a survey in northern Viet Nam and Cambodia, PLOS ONE, 7, e37986

Fournie, G., Guitian, J., Desvaux, S., Cuong, V.C., Dung, D.H., Pfeiffer, D.U., Mangtani, P. and Ghani, A.C., 2013. Interventions for avian influenza A (H5N1) risk management in live bird market networks, Proceedings of the National Academy of Sciences of the United States of America, 110, 9177-9182

Frantz, T.L., 2012. Advancing complementary and alternative medicine through social network analysis and agent-based modeling, Forsch Komplementmed, 19 Suppl 1, 36-41
Martin, V., Zhou, X., Marshall, E., Jia, B., Fusheng, G., FrancoDixon, M.A., DeHaan, N., Pfeiffer, D.U., Soares Magalhaes, R.J. and Gilbert, M., 2011. Risk-based surveillance for avian influenza control along poultry market chains in south China: the value of social network analysis, Preventive Veterinary Medicine, 102, 196-205

Paul, M., Wongnarkpet, S., Gasqui, P., Poolkhet, C., Thongratsakul, S., Ducrot, C. and Roger, F., 2011. Risk factors for highly pathogenic avian influenza (HPAI) H5N1 infection in backyard chicken farms, Thailand, Acta Tropica, 118, 209-216

Paul, M., Baritaux, V., Wongnarkpet, S., Poolkhet, C., Thanapongtharm, W., Roger, F., Bonnet, P. and Ducrot, C., 2013. Practices associated with highly pathogenic avian influenza spread in traditional poultry marketing chains: social and economic perspectives, Acta Tropica, $126,43-53$

Poolkhet, C., Chairatanayuth, P., Thongratsakul, S., Yatbantoong, N., Kasemsuwan, S., Damchoey, D. and Rukkwamsuk, T., 2012. Social network analysis for assessment of avian influenza spread and trading patterns of backyard chickens in Nakhon Pathom, Suphan Buri and Ratchaburi, Thailand, Zoonoses and Public Health, 60, 448-455

Poolkhet, C., Chairatanayuth, P., Thongratsakul, S., Kasemsuwan, S. and Rukkwamsuk, T., 2013. Social network analysis used to assess the relationship between the spread of avian influenza and movement patterns of backyard chickens in Ratchaburi, Thailand, Research in Veterinary Science, 95, 82-86

Sadler, G.R., Lee, H.C., Lim, R.S. and Fullerton, J., 2010. Recruitment of hard-to-reach population subgroups via adaptations of the snowball sampling strategy, Nursing and Health Sciences, 12, 369-374

Siengsanan-Lamont, J., Robertson, I.D., Blacksell, S.D., Ellis, T., Saengchoowong, S., Suwanpukdee, S., Yongyuttawichai, P., Cheewajorn, K., Jangjaras, J., Chaichoun, K., Wiriyarat, W. and Ratanakorn, P., 2013. A study of risk factors for infection with HPAI H5N1 in small poultry farms in Thailand using a questionnaire survey, Zoonoses and Public Health, 60, 209-214

Soares Magalhães, R.J., Ortiz-Pelaez, A., Lai Thi, K.L., Dinh, T.T., Otte, J. and Pfeiffer, D.U., 2010. Associations between attributes of live poultry trade and HPAI H5N1 outbreaks: a descriptive and network analysis study in northern Vietnam, BMC Veterinary Research, 6

Soares Magalhaes, R.J., Zhou, X., Jia, B., Guo, F., Pfeiffer, D.U. and Martin, V., 2012. Live poultry trade in southern China provinces and HPAIV H5N1 infection in humans and poultry: the role of Chinese New Year festivities, PLOS ONE, 7, e49712

Tiensin, T., Chaitaweesub, P., Songserm, T., Chaisingh, A., Hoonsuwan, W., Buranathai, C., Parakamawongsa, T., Premashthira, S., Amonsin, A., Gilbert, M., Nielen, M. and Stegeman, A., 2005. Highly pathogenic avian influenza H5N1, Thailand, 2004, Emerging Infectious Diseases, 11, 1664-1672

Tiensin, T., Ahmed, S.S., Rojanasthien, S., Songserm, T., Ratanakorn, P., Chaichoun, K., Kalpravidh, W., Wongkasemjit, S., Patchimasiri, T., Chanachai, K., Thanapongtham, W., Chotinan, S., Stegeman, A. and Nielen, M., 2009. Ecologic risk factor investigation of clusters of avian influenza A (H5N1) virus infection in Thailand, Journal of Infectious Diseases, 199, 1735-1743

Van Kerkhove, M.D., Vong, S., Guitian, J., Holl, D., Mangtani, P., San, S. and Ghani, A.C., 2009. Poultry movement networks in Cambodia: implications for surveillance and control of highly pathogenic avian influenza (HPAI/H5N1), Vaccine, 27, 6345-6352 